xương là $45 \%$, típ nguyên bào xơ là $35 \%$, các týp độ cao khác là $40 \%$, với sarcom xương độ thấp là $50 \%(p>0,05)$. Kết quả nghiên cứu này tương tự nhận xét của Hauben [9] khi nghiên cứu trên 570 bệnh nhân sarcom xương trong một thử nghiệm lâm sàng lớn ở Châu Âu.

Số bệnh nhân sarcom xương độ thấp của chúng tôi chỉ có 2 bệnh nhân nên không đủ số lượng để có thể đưa ra nhận xét. Nhưng tham chiếu với $\mathrm{y}$ văn thì có thể nhận thấy rằng các sarcom xương độ thấp có tỷ lệ sống sót cao hơn so với các sarcom xương độ cao.

\section{KẾT LUẬN}

Với 123 bệnh nhân trong nghiên cứu, các típ mô học độ cao chiếm tỉ lệ $98,37 \%$. Thứ tự các típ mổ bệnh học phổ biến nhất, theo chiều giảm dần, là típ nguyên bào xương $(54,47 \%)$, nguyên bào $x$ ơ $(154,5 \%)$ và nguyên bào sụn $(9,76 \%)$ $(p<0,05)$. Các típ mô học có mối liên quan đến xác suất sống còn, nhưng sự khác biệt không có ý nghĩa thống kê $(p>0,05)$.

\section{TÀI LIÊU THAM KHẢO}

1. Ferlay J, Colombet $M$, Soerjomataram $I$, Mathers $C$, Parkin $D$, Piñeros $M$, et al. Estimating the global cancer incidence and mortality in 2018: GLOBOCAN sources and methods. International journal of cancer. 2019;144(8):1941-53.

2. Bridge J, Hogendoorn P, DM C, Bridge JA, CW P, Fletcher CD. WHO classification of tumours of soft tissue and bone: International Agency for Research on Cancer; 2013.
3. Bacci G, Longhi A, Versari $M$, Mercuri $M$, Briccoli A, Picci P. Prognostic factors for osteosarcoma of the extremity treated with neoadjuvant chemotherapy: 15-year experience in 789 patients treated at a single institution. Cancer: Interdisciplinary International Journal of the American Cancer Society. 2006;106(5):1154-61.

4. Ries L. SEER cancer statistics review, 19752002. http://seer cancer gov/csr/1975_2002/. 2002.

5. Mirabello L, Troisi RJ, Savage SA. Osteosarcoma incidence and survival rates from 1973 to 2004: data from the Surveillance, Epidemiology, and End Results Program. Cancer: Interdisciplinary International Journal of the American Cancer Society. 2009;115(7):1531-43.

6. Minh VT. Nhận xét về đă̆c điểm lâm sàng, $X$ quang, mô bệnh học và kết quả điều trị ung thư xương nguyên phát tại bệnh viện K. Hà Nội: Trường Đại học Y Hà Nội; 2000.

7. Công TV. Nghên cứu điêu trị sacôm tạo xương giai đoạn II bằng phẫu thuật và hóa chất phác đồ doxorubicin, cisplatin tại Bệnh viện K. Hà Nội: Đại hoc Y Hà Nội; 2009.

8. Bielack SŚ, Kempf-Bielack B, Delling Gn, Exner GU, Flege S, Helmke K, et al. Prognostic factors in high-grade osteosarcoma of the extremities or trunk: an analysis of 1,702 patients treated on neoadjuvant cooperative osteosarcoma study group protocols. Journal of clinical oncology. 2002;20(3):776-90.

9. Hauben E, Weeden S, Pringle J, Van Marck E, Hogendoorn P. Does the histological subtype of high-grade central osteosarcoma influence the response to treatment with chemotherapy and does it affect overall survival? A study on 570 patients of two consecutive trials of the European Osteosarcoma Intergroup. European Journal of Cancer. 2002;38(9):1218-25.

\title{
ĐẶC ĐIỂM SANG CHẤN TÂM LÝ Ở NGƯờI BÊNH RỐI LOẠN LOẠN THẦN CẤP VÀ NHẤT THỜ'I
}

\section{TÓM TẮT}

Mục tiêu: Mô tả đặc điểm sang chấn tâm lý ở người bệnh rối loạn loạn thần cấp và nhất thời. Đối tượng và phương pháp: Sử dưng phương pháp mô tả cắt ngang, phân tích đặc điểm sang chẩn tâm lý bằng phỏng vấn trực tiếp bệnh nhân và người nhà bênh nhân được điều tri nội trú tại Viên Sức khỏe Tâm thần- Bệnh viện Bạch Mai. Kết quả: 57 bệnh nhân có sang chấn tâm lý trong số 81 bệnh nhân rối loạn loạn

\footnotetext{
${ }^{1}$ Viện Sức khoẻ Tâm thần - Bệnh viện Bạch Mai, ${ }^{2}$ Trường Đai hoc Y Hà Nôi

Chịu trách nhiệm chính: Đoàn Thị Huệ

Email: doanthihue@hmu.edu.vn

Ngày nhận bài: 25.6.2021

Ngày phản biên khoa hoc: 23.8.2021

Ngày duyệt bài: 30.8.2021
}

Đoàn Thị Huệ ${ }^{1}$, Dương Minh Tâm ${ }^{1,2}$

thần cấp và nhất thời chiếm tỷ lệ $70,4 \%$. Phân tích 57 bệnh nhân có sang chấn tâm lý chúng tôi thấy: khó khăn về kinh tế là sang chấn tâm lý gặp nhiêu nhất, chiếm $29,6 \%$, không có bệnh nhân nào mà nghỉ hưu là sang chấn tâm lý. Chủ yếu sang chấn tâm lỳ xảy ra trước khi bị bệnh trên 2 tuần, chiếm $54,3 \%$. Phần lớn sang chấn tâm lý có cường độ và ý nghĩa ở mức độ vừa $(50,6 \%$ và $58,0 \%)$. Kểt luận: Rối loạn loạn thần cấp và nhất thời có tỳ lệ cao các sang chấn tâm lý, phân lớn là các sang chấn về vấn đề kinh tế khó khăn, cường độ và ý nghĩa sang chấn chủ yếu ở mức độ vừa phải.

Từ khóa: Rối loạn loạn thân cấp và nhất thời, sang chấn tâm lý

\section{SUMMARY \\ CHARACTERISTICS OF PSYCHOLOGICAL TRAUMA IN PATIENTS WITH ACUTE AND TRANSIENT PSYCHOSIS}


Objective: To describe the characteristics of psychological trauma in patients with acute and transient psychosis. Subjects and methods: Using a cross-sectional study, to analyze psychological trauma characteristics by directly interviewing patients and their family members who were treated as inpatients at the National Institute of Mental Health - Bach Mai Hospital. Results: 57 patients had psychological trauma out of 81 patients with acute and transient psychosis, accounting for $70.4 \%$. Analysis of 57 patients with psychological trauma, we found: economic difficulties are the most common psychological trauma, accounting for $29.6 \%$, there is no patient whose retirement is psychological trauma. Mainly psychological trauma occurred more than 2 weeks before the illness, accounting for $54.3 \%$. Most psychological trauma was of moderate intensity and significance (50.6\% and $58.0 \%)$. Conclusions: Acute and transient psychotic disorders have a high rate of psychological trauma, most of which are economic hardships, and the intensity and significance of the trauma are mostly moderate.

Keywords: Acute and transient psychotic disorder, psychological trauma.

\section{I. ĐĂT VẤN ĐỀ}

Rối loan loạn thần cấp và nhất thời là những rối loạn khởi phát cấp tính, không đáp ứng tiêu chuẩn chẩn đoán của tâm thần phân liệt. Các rối loạn này có những đặc điểm chung như khởi phát đột ngột, cấp tính từ trạng thái tâm thần bình thường sang trang thái loạn thần hoàn toàn trong vòng một vài tuần, thậm chí vài ngày, bệnh có thể xảy ra sau sang chấn tâm lý,...[1].

Bảng phân loại bệnh Quốc tế lần thứ 10 về rối loạn tâm thần và hành vi (ICD-10) cho thấy có một tỷ lệ nhất định các rối loạn loạn thấn cấp và nhất thời kết hợp với sang chấn tâm lý. Các sự kiện gây sang chấn tâm lý có thể là tang tóc, mất mát tài sản lớn, sang chấn trong chiến đấu bị khủng bố bị tra tấn, cùng có thể sự thất vọng trong cuộc sống lứa đôi. Các triệu chứng loạn thần đầu tiên phải xuất hiện trong vòng hai tuần sau một hay nhiều sự kiện được xem như là sang chấn [2]. Theo Marija Rusaka và cộng sự (2014), khi tiến hành nghiên cứu về rối loạn loạn thần cấp và nhất thời cho thây có tới $43,8 \%$ bênh nhân có các sự kiện căng thẳng trong cuộc sống kéo dài trong sáu tháng trước khi xuất hiện các triệu chứng rối loạn tâm thần [3].

ở Việt Nam chưa có công trình nào nghiên cứu về đặc điểm sang chấn tâm lý của Rối loạn loạn thần cấp và nhất thời, để giúp cho các thầy thuốc chẩn đoán đúng, sớm hơn, nâng cao hiệu quả điều trị và tiên lượng bệnh. Do vậy, chúng tôi tiến hành nghiên cứu đề tài này với mục tiêu:
Mô tả đăc điểm yếu tố sang chấn tâm lý ở người bệnh rối loạn loạn thần cấp và nhất thời.

\section{II. ĐỐI TƯỢNG VÀ PHƯƠNG PHÁP NGHIÊN CỨU}

Đối tượng nghiên cứu: 81 bệnh nhân, trong đó có 57 bệnh nhân có sang chấn tâm lý điều trị nội trú tại Viện Sức khoẻ Tâm thần, thỏa mãn tiêu chuẩn chẩn đoán (ICD-10F) 1992 của Tổ chức $Y$ tế Thế giới. Thời gian nghiên cứu: 07/2020 - 03/2021.

Phương pháp nghiên cứu: Nghiên cứu mô tả cắt ngang, phân tích đặc điểm sang chấn tâm lý thông qua phỏng vấn trực tiếp bệnh nhân và người nhà khi nằm viện. Xử lý số liệu bằng phần mềm SPSS 25.0.

\section{KẾT QUẢ NGHIÊN CỨU}

\section{Tỷ lệ và phân bố nội dung của sang} chấn tâm lý

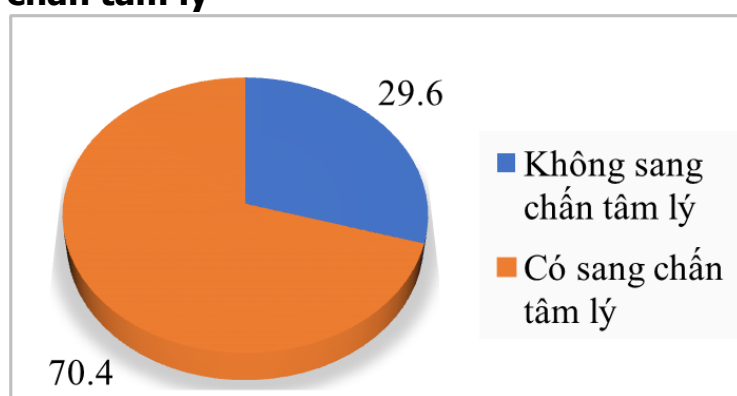

Biểu đồ 3.1: Tỷ lệ sang chấn tâm lý

Nhận xét: Trong nghiên cứu của chúng tôi, bệnh nhân có sang chấn tâm lý chiếm tỷ lệ cao (70,4\%)

Bảng 3.1: Phân bố nội dung các sang chấn tâm lý

\begin{tabular}{|c|c|c|}
\hline & $\mathbf{n}$ & $\mathbf{0}$ \\
\hline Người thân mất & 2 & 2,5 \\
\hline Ly hôn & 2 & 2,5 \\
\hline Mâu thuân trong gia đình & 15 & 18,5 \\
\hline Khó khăn về kinh tế & 24 & 29,6 \\
\hline Về hưu & 0 & 0 \\
\hline Mâu thuân trong xã hội & 6 & 7,4 \\
\hline Tan vỡ trong tình cảm & 9 & 11,1 \\
\hline Khác & 14 & 17,3 \\
\hline
\end{tabular}

Nhận xét: Khó khăn kinh tế là sang chấn tâm lý chiếm tỷ lệ cao nhất là $29,6 \%$, sau đó là các sang chấn tầm lý về mâu thuẫn trong gia đình chiếm 18,5\%. Các sang chấn tâm lý như tan võ̃ tình cảm, mâu thuẫn trong xã hội chiếm tỷ lệ thấp hơn lần lượt là $11,2 \%$ và $7,4 \%$.

\section{2. Đặc điểm của sang chấn tâm lý}


Bảng 3.2. Thời gian xuât hiện sang chấn tâm lý

\begin{tabular}{|c|c|c|c|c|c|c|c|c|}
\hline & \multicolumn{2}{|c|}{$<=\mathbf{4 8 h}$} & $\mathbf{4 8 h}-\mathbf{2}$ tuân & \multicolumn{2}{c|}{$>\mathbf{2}$ tuần } & \multicolumn{2}{c|}{ Tống } \\
\cline { 2 - 9 } & $\mathbf{n}$ & $\mathbf{\%}$ & $\mathbf{n}$ & $\mathbf{\%}$ & $\mathbf{n}$ & $\mathbf{\%}$ & $\mathbf{n}$ & $\mathbf{\%}$ \\
\hline Người thân mất & 0 & 0 & 0 & 0 & 2 & 2,5 & 2 & 2,5 \\
\hline Ly hôn & 0 & 0 & 0 & 0 & 2 & 2,5 & 2 & 2,5 \\
\hline Mâu thuân trong gia đình & 0 & 0 & 5 & 6,2 & 10 & 12,3 & 15 & 18,5 \\
\hline Khó khăn về kinh tế & 1 & 1,2 & 8 & 9,9 & 15 & 18,5 & 24 & 29,6 \\
\hline Về hưu & 0 & 0 & 0 & 0 & 0 & 0 & 0 & 0 \\
\hline Mâu thuân trong xã hội & 0 & 0 & 2 & 2.5 & 4 & 4,9 & 6 & 7,4 \\
\hline Tan vơ trong tinh cảm & 2 & 2,5 & 2 & 2,5 & 5 & 6,2 & 9 & 11,1 \\
\hline Khác & 0 & 0 & 8 & 9,9 & 6 & 7,4 & 14 & 17,3 \\
\hline Tống & $\mathbf{3}$ & $\mathbf{3 , 7}$ & $\mathbf{2 5}$ & $\mathbf{3 0 , 9}$ & $\mathbf{4 4}$ & $\mathbf{5 4 , 3}$ & $\mathbf{7 2}$ & \\
\hline
\end{tabular}

Nhận xét: Chủ yếu bệnh nhân gặp sang chấn tâm lý trên 2 tuần trước khi có các triệu chứng loạn thần chiếm $54,3 \%$, 48h-2 tuần trước khi xuất hiện các triệu chứng loạn thần chiếm tỷ lệ thấp hớn là 30,9\%,< = 48h trước khi có triệu chứng loạn thần chiếm tỷ lệ thấp nhất 3,7\%.

Bảng 3.3: Cường độ sang chấn tâm lý

\begin{tabular}{|c|c|c|c|c|c|c|c|c|}
\hline & \multicolumn{2}{|c|}{ Mạnh } & \multicolumn{2}{c|}{ Vừa phải } & \multicolumn{2}{|c|}{ Nhe } & \multicolumn{2}{c|}{ Tổng } \\
\cline { 2 - 9 } & $\mathbf{n}$ & $\mathbf{\%}$ & $\mathbf{n}$ & $\mathbf{\%}$ & $\mathbf{n}$ & $\mathbf{\%}$ & $\mathbf{n}$ & $\mathbf{\%}$ \\
\hline Người thân mất & 1 & 1,2 & 1 & 1,2 & 0 & 0 & 2 & 2,5 \\
\hline Ly hôn & 0 & 0 & 1 & 1,2 & 1 & 1,2 & 2 & 2,5 \\
\hline Mâu thuân trong gia đình & 4 & 4,9 & 10 & 12,3 & 1 & 1,2 & 15 & 18,5 \\
\hline Khó khăn về kinh tế & 5 & 6,2 & 14 & 17,3 & 5 & 6,2 & 24 & 29,6 \\
\hline Vền hưu & 0 & 0 & 0 & 0 & 0 & 0 & 0 & 0 \\
\hline Mâu thuânn trong xã hội & 2 & 2,5 & 4 & 4,9 & 0 & 0 & 6 & 7,4 \\
\hline Tan võ trong tình cảm & 2 & 2,5 & 5 & 6,2 & 2 & 2,5 & 9 & 11,1 \\
\hline Khác & 6 & 7,4 & 6 & 7,4 & 2 & 2,5 & 14 & 17,3 \\
\hline Tống & $\mathbf{2 0}$ & $\mathbf{2 4 , 7}$ & $\mathbf{4 1}$ & $\mathbf{5 0 , 6}$ & $\mathbf{1 1}$ & $\mathbf{1 3 , 6}$ & $\mathbf{7 2}$ & \\
\hline
\end{tabular}

Nhận xét: Phần lớn cường độ sang chấn tâm lý ở mức độ vừa phải, chiếm $50,6 \%$, tiếp đến là nhóm sang chấn tâm lý cường độ mạnh chiếm tỷ lệ thấp hơn là $24,7 \%$. Nhóm sang chấn tâm lý có cường độ nhe chiềm tỷ lệ thấp nhất 13,6\%.

Bảng 3.4: Ý nghĩa sang chấn

\begin{tabular}{|c|c|c|c|c|c|c|c|c|}
\hline & \multicolumn{2}{|c|}{ Nhî̀u } & \multicolumn{2}{c|}{ Vừa phải } & \multicolumn{2}{|c|}{ It } & \multicolumn{2}{c|}{ Tống } \\
\cline { 2 - 9 } & $\mathbf{n}$ & $\mathbf{\%}$ & $\mathbf{n}$ & $\mathbf{\%}$ & $\mathbf{n}$ & $\mathbf{\%}$ & $\mathbf{n}$ & $\mathbf{\%}$ \\
\hline Người thân mất & 2 & 2,5 & 0 & 0 & 0 & 0 & 2 & 2,5 \\
\hline Ly hôn & 0 & 0 & 1 & 1,2 & 1 & 1,2 & 2 & 2,5 \\
\hline Mâu thuân trong gia đình & 4 & 4,9 & 10 & 12,3 & 1 & 1,2 & 15 & 18,5 \\
\hline Khó khăn về kinh tế & 2 & 2,5 & 20 & 24,5 & 2 & 2,5 & 24 & 29,6 \\
\hline Về hưu & 0 & 0 & 0 & 0 & 0 & 0 & 0 & 0 \\
\hline Mâu thuân trong xã hội & 0 & 0 & 6 & 7,4 & 0 & 0 & 6 & 7,4 \\
\hline Tan vỡ trong tình cảm & 2 & 2,5 & 4 & 4,9 & 3 & 3,7 & 9 & 11,1 \\
\hline Khác & 7 & 8,6 & 6 & 7,4 & 1 & 1,2 & 14 & 17,3 \\
\hline Tống & $\mathbf{1 7}$ & $\mathbf{2 1 , 0}$ & $\mathbf{4 7}$ & $\mathbf{5 8 , 0}$ & $\mathbf{8}$ & $\mathbf{9 , 9}$ & $\mathbf{7 2}$ & \\
\hline
\end{tabular}

Nhận xét: Chủ yếu bệnh nhân đánh giá sang chấn tâm lý của mình là có ý nghĩa vừa phải, chiếm $58,0 \%$. Nhóm sang chấn tâm lý có ý nghĩa nhiêu chiếm tỷ lệ thấp hơn $(21,0 \%)$. Nhóm sang chấn tâm lý có ý nghĩa rất ít chiếm tỷ lệ thấp nhất $(9,9 \%)$.

\section{BÀN LUÂN}

1. Tỷ lệ và phân bố nội dung của sang chấn tâm lý

*Tỷ lệ sang chấn tâm lý. Trong nghiên cứu của chúng tôi (biểu đồ 3.1), cho thấy bệnh nhân có sang chấn tâm lý chiếm tỷ lệ khá cao $70,4 \%$. Kết quả của chúng tôi là khác với nhiều nghiên cứu khác như: theo Vương Đình Thuỷ (2017) khi nghiên cứu trên 75 bệnh nhân rối loạn loạn thần cấp cho thấy có $16 \%$ bệnh nhân có sang chấn tâm lý [4]. Điều này có thể lý giải là các sang chấn tâm lý mà bệnh nhân có là tất cả các sang chấn tâm lý mà bệnh nhân gặp trước khi xuất hiện các triệu chứng rối loạn tâm thần, còn các sang chấn tâm lý trong nghiên cứu trên chỉ tính trong thời gian dưới hai tuần. Chính vì thế nên sự khác biệt này có thể chấp nhân được. Tuy nhiện, kết quả của chúng tôi cũng thấp hơn 
nhiều nghiện cứu trên thế giới, theo Rusaka (2014) khi nghiên cứu trên 314 bệnh nhân rối loạn loạn thần cấp cho thấy có $3,4 \%(n=10)$ bệnh nhân có sang chấn tâm lý theo đúng tiêu chuẩn ICD 10 (sang chấn tâm lý xuất hiện trong vòng 2 tuần trước khi có các rối loạn loạn thần) và $43,8 \%$ bệnh nhân có sang chấn tâm lý trong vòng 6 tháng trước khi được chẩn đoán rối loạn loạn thần cấp và nhất thời. Tương tự, theo Castagnini (2015) khi tiến hành so sánh các rối loạn tâm thần cấp tính cũng cho thây, các sang chấn tâm lý được báo cáo trong 21 trường hợp $(44,7 \%)$ với rối loạn loạn thần cấp và nhất thời và $8(17,0 \%)$ ở nhóm bệnh nhân rối loạn cấp tính khác, có liên quan đển căng thẳng cấp tính trong vòng 2 tuần sau khi khởi phát triệu chứng [5] . Sự khác biệt này có thể do cỡ mẫu và phương pháp nghiên cứu không giống nhau, cùng với nền văn hoá khác nhau có thể tạo nên sự khác biệt này.

*Nội dung của sang chấn tâm lý. Theo bảng 3.1 , cho thấy nội dung của sang chấn tâm lý hay gặp nhất là khó khăn về kinh tế $(29,6 \%)$ và mâu thuẫn trong gia đình $(18,5 \%)$. Còn lại mâu thuẫn trong xã hội $(7,4 \%)$, tan võ trong tình cảm $(11,1 \%)$, người thân mất $(2,5 \%)$ và ly hôn (2,5\%). Theo Vương Đình Thuỷ (2017) cũng cho kết quả tương tự, mâu thuẫn trong gia đình $(32,0 \%)$ và khó khăn thiệt hại về kinh tế $(28,0 \%)$. Còn lại mâu thuẫn trong xã hội $(16,0 \%)$, tan võ trong tình cảm $(12,0 \%)$, người thân mất $(8,0 \%)$ và vấn đề về con cháu $(4,0 \%)$. Tuy nhiên, theo nghiên cứu của Marija Rusaka (2015) có sự khác biệt ở sang chấn hay gặp nhất liên quan đến xã hội (thay đổi công việc, vấn đề nặng nề trong công việc) (29,4\% và $17,0 \%)$, còn lại kết quả khá tương đông như sự mất mát người thân $(13,1 \%)$, vấn đề nghiêm trọng trong gia đình $(20,1 \%)$, sự chia ly $(16,2 \%)$ [6]. Sứ khác biệt này có lẽ do đặc điểm về văn hóa, lối sống của người Việt Nam thường sống trong gia đình với mối quan hệ mật thiết với nhau và quan điểm sống vì gia đình.

\section{2. Đặc điểm của sang chấn tâm lý}

*Đăc điểm về tính chất xuất hiên của sang chấn tâm lý. Theo bảng 3.2, cho thấy phần lớn các bệnh nhân nghiên cứu có thời gian xuất hiện sang chấn tâm lý là trên 2 tuần trước khi có các triệu chứng loạn thần chiêm 54,3\%. Nhóm bênh nhân có thời gian xuất hiên sang chấn tâm lý từ 48h đến 2 tuần trước khi có triệu chứng loạn thần chiếm tỷ lệ thấp hơn $(30,9)$. Chỉ có 3 bệnh nhân có thời gian xuất hiện sang chấn tâm lý <= 48h trước khi có triệu chứng loạn thần
(3,7\%). Teo Castagnini (2015) [5] khi tiến hành nghiên cứu trên 47 bệnh nhân rối loạn loạn thần cấp và nhất thời cho kết quả $17,0 \%$ bênh nhân có sang chấn tâm lý $<=2$ tuần trước khi có các triệu chứng loạn thần và $27,7 \%$ bệnh nhân có sang chấn tâm lý $<=3$ tháng trước khi có triệu chứng loạn thần. Như vậy kết quả nghiên cứu của chúng tôi là khác so với nghiên cứu trên. Điều này có thể được giải thích là do cõ mẫu, thiết kế nghiên cứu là không giống nhau và hai quốc gia với nền văn hoá, phong tục tập quán, tôn giáo, kinh tế khác nhau. Chính vì lý do trên có thể tạo ra sự khác biệt này.

*Đặc điểm về cường độ và ý nghĩa của sang chấn tâm lý. Theo bảng 3.3, cho thấy phần lớn các sang chấn tâm lý được bệnh nhân nhận định là có cường độ vừa phải chiếm $50,6 \%$. Các sang chấn tâm lý được bệnh nhân cho là mức độ manh chiếm tỷ lệ thấp hơn $24,7 \%$ và sang chấn tâm lý được cho là mức độ nhe chiếm tỷ lệ thấp nhất 13,6\%. Tuy nhiên nhóm sang chấn tâm lý là ly hôn thì không có bệnh nhân nhân nào nhận thấy đây là một sang chấn tâm lý mạnh. Điều này có thể do số lượng bệnh nhân ly hôn trong mầu nghiên cứu là quá thấp (2 bệnh nhân) nên tỷ lệ trên cũng là phù hợp. Hơn nữa, trong xã hội hiện đại, việc bình đẳng nam nữ, việc kết hôn hay ly hôn không còn là vấn đề quá quan trọng và căng thẳng. Có thể vì thế mà việc ly hôn không phải là sang chấn quá mạnh đối với bệnh nhân nói riêng và mọi người nói chung.

Trong nghiên cứu của chúng tôi (bảng 3.4), phần lớn các sang chấn tâm lý được bệnh nhân cho là có ý nghĩa vừa phải với mình, chiếm $58,0 \%$. Sang chấn tâm lý được bênh nhân cho là có ý nghĩa rất lớn với bản thần mình chiếm tỷ lệ thấp hơn (21,0\%). Thấp nhất là nhóm sang chấn tâm lý mà bệnh nhân thấy có ít có ý nghĩa với mình chiếm $9,9 \%$. Tuy nhiên, khi xét riệng từng sang chấn tâm lý thì thấy rằng, chỉ có nhóm sang chấn tâm lý là mất người thân và sang chấn tâm lý khác là bệnh nhân cho là chúng có ý nghĩa rất lớn với mình, chiềm tỷ lệ lần lượt là $2,5 \%$ và $8,6 \%$. Điều này có thể là phù hợp. Vì sang chấn tâm lý là mất người thân thường là sang chấn mạnh, cấp diễn, xảy ra lần đâuu nên nó có ý nghĩa quan trọng đối với bệnh nhân.

Có thể nói, sang chấn tâm lý có thể gây bệnh thường là những sang chấn tâm lý manh và cấp diễn (người thân chết đột ngột, tổn thất nặng nề về kinh tế...). Những sang chấn tâm lý không mạnh nhưng lặp đi, lặp lại nhiều lần gây căng thẳng tâm lý (những căng thẳng, mâu thuẫn trong cuộc sống, bất hòa vợ chồng...) cũng có 
khả năng gây bệnh nếu cá thể phòng vệ và đối phó kém. Tuy nhiên, thành phần gây bểnh của sang chấn tâm lý là ý nghĩa thông tin chứ không chỉ là cường độ của sang chấn và ý nghĩa thông tin đóng vai trò quan trọng hơn.

\section{KẾT LUẬN}

Bệnh nhân rối loạn loạn thần cấp và nhất thời có tỷ lệ cao có sang chấn tâm lý

Phần lớn sang chấn tâm lý là khó khăn về kinh tế và xuất hiện trên 2 tuần trước khi bị bệnh, có cường độ, ý nghĩa ở mức vừa phải.

\section{TÀI LIẸU THAM KHẢO}

1. Trần Hữu Bình (2001). Rối loạn loạn thần cấp và nhất thời. Bênh học tâm thần. Bộ mồn tâm thần Đai học Y Hà Nội, 38-43.

2. Tổ chức y tế thế giới (WHO) (1992), Rối loạn loạn thần cấp và nhất thời, Phân loại cảc rối loạn tâm thần và hành vi ICD-10, World Health Organization, Geneva, 91-94.

3. Rusaka M. and Rancāns E. (2014). A prospective follow-up study of first-episode acute transient psychotic disorder in Latvia. Ann Gen Psychiatry, 13(1), 4.

4. Vương Đình Thuỷ (2018), Nghiên cứu đặc điểm lâm sàng và một số yếu tố liên quan đến rối loạn loạn thần cấp và nhất thời, luận văn cao học, Trường đại học Y Hà Nội, Hà Nội., .

5. Castagnini A.C., Munk-Jørgensen $P_{.}$, and Bertelsen A. (2016). Short-term course and outcome of acute and transient psychotic disorders: Differences from other types of psychosis with acute onset. Int J Soc Psychiatry, 62(1), 51-56.

6. Marija R. (2015), Acute and Transient Psychotic Disorder (ATPD) Dynamic Development and Particularities in Diagnostics and Treatment in Latvia. Summary of the Doctoral Thesis, Dr. med., Rīga Stradinš University.

\section{ĐĂC ĐIỂM LÂM SÀNG, CÂ̂N LÂM SÀNG BỆNH NHÂN UNG THƯ PHỔI KHÔNG TẾ BÀO NHỎ DI CĂN NÃO CÓ ĐộT BIẾN EGFR TẠI BỆNH VIỆN BẠCH MAI}

\section{TÓM TẮT}

Mục tiêu: Mô tả đặc điểm bệnh nhân ung thư phổi không tế bào nhỏ di căn não có đột biến EGFR tại Bệnh viện Bạch Mai. Đối tượng và phương pháp nghiên cứu: Nghiên cứu hồi cứu, mô tả, cắt ngang trên 53 bệnh nhân được chẩn đoán ung thư phổi không tế bào nhỏ di căn não có đột biến gen EGFR được điều trị thuốc ức chế tyrosine kinase kết hợp xạ phẩu dao gamma quay tại Trung tâm Y học hạt nhân và Ung bướu Bệnh viện Bạch Mai thời gian từ 01/2016 đến 12/2020. Kết quả: 50,9\% nam, tỷ lệ nam/nữ: 1,04/1, chủ yếu ở độ tuổi 50-69 (73,6\%). 43,4\% bệnh nhân hút thuốc lá, chỉ gặp ở nam giới. Triệu chứng hay gặp là triệu chứng hô hấp $54,7 \%$, tiểp đến là chứng thần kinh $39,6 \%$. Đa số bệnh nhân có chỉ số toàn trạng PS ECOG từ 0-1 $(81,1 \%)$. Giai đoan T1-2 gặp $64,2 \%$, di căn hạch $58,5 \%$, di căn não thường kết hợp di căn vị trí khác $(64,2 \%)$ trong đó hay gặp nhất là di căn xương 49,1\%, tiếp đến là di căn phổi, màng phổi $28,3 \%$, tuyến thượng thận $5,7 \%$, gan 3,7\%. Đặc diểm u di căn não: Di căn 1 ổ gặp 47\%, vị trí hay di căn là bán câu đại não $(79,2 \%)$, kích thước từ 1 $20 \mathrm{~mm}$ chiếm tỷ lệ cao nhất $(69,9 \%)$, kích thước nhỏ

${ }^{1}$ Bênh viên quân y 110

2Trung tâm Y học hạt nhân và Ung bướu, Bệnh viện Bach Mai

Chịu trách nhiệm chính: Nguyễn Văn Kiên

Email: Dr.Kien39A@gmail.com

Ngày nhận bài: 25.6.2021

Ngày phản biện khoa học: 23.8.2021

Ngày duyệt bải: 30.8 .2021

\section{Nguyễn Văn Kiên ${ }^{1}$, Phạm Cẩm Phương ${ }^{2}$}

1-10mm chiếm 20,1\%. Tỷ lệ bệnh nhân có đột biến Del19 chiếm đa số $(67,9 \%)$, Del $19 / L 858 R=2,77 / 1$. So với đột biến exon 21 , đột biến Del 19 gặp nhiều ở nhóm nữ hơn $(63,9 \%)$ sự khác biệt có ý nghĩa thống kê với $p=0,005$. Đa số bệnh nhân có nồng độ CEA, cyfra 21-1 đêu cao hơn ngưỡng bình thường (81,8\% và $70,3 \%)$. Di căn xương có mối liên hệ chặt chẽ với tình trạng tăng CEA bất thường với $\dot{p}=0,047$. Kết luân: Bênh nhân ung thư phổi di căn não có đôt biến EGFR có tỷ lệ nam/ nữ cân bằng, đột biến Del 19 chiếm đa số, găp nhiều ở nữ. CEA có đô nhay cao trong dự báo tình trạng di căn toàn thân, đặc biệt là di căn xướng.

Tư khóa: ung thư phổi di căn não, đột biến EGFR, đặc điểm bệnh nhân, CEA

\section{SUMMARY}

CHARACTERISTICS OF CLINICAL AND

PARACLINICAL OF NON-SMALL CELL LUNG CANCER PATIENTS WITH EPIDERMAL GROWTH FACTOR RECEPTOR MUTANT AND BRAIN METASTASIS TREATED AT BACH MAI HOSPITAL

Object: Characterizing of non-small cell lung cancer patients with epidermal growth factor receptor mutant and brain metastasis treated at Bach Mai Hospital. Patient and Methods: Retrospective, descriptive, cross-sectional, studying on 53 epidermal growth factor receptor, brain metastasis of mutant non-small cell lung cancer patients treated with tyrosine kinase inhibitors plus Rotating Gamma System Radiosurgery at the Nuclear Medicine and Oncology Center of Bach Mai Hospital from January 2016 to December 2020. Results: $50.9 \%$ male, male/female 